Thorax (1965), 20, 337.

\title{
Bicarbonate buffering in acute exacerbation of chronic respiratory failure
}

\author{
GEORGE J.ADD IS \\ From the Southern General Hospital, Glasgow ${ }^{1}$
}

Though the low blood $p \mathrm{H}$ values which are found in acute respiratory failure have been well recognized, few attempts appear to have been made to treat this acidosis directly as well as indirectly by improving the ventilation. In their classic paper, Westlake, Simpson, and Kaye (1955) emphasized the importance of blood $p \mathrm{H}$ levels, particularly in relation to the level of consciousness, and suggested that this effect was not necessarily due to the combination of low $p \mathrm{H}$ levels with a high arterial carbon dioxide tension $\left(\mathrm{PaCO}_{2}\right)$. They also drew attention to the evidence of Kety, Polis, Nadler, and Schmidt (1948) that cerebral oxygen consumption is reduced in the presence of a low blood $\mathrm{pH}$.

This association of low $p \mathrm{H}$ values with clouding of consciousness seemed so striking that when a patient (case 1) developed a further exacerbation of his bronchitis after a year of observation and treatment with continuous oxygen, antibiotics, and latterly a permanent tracheostomy, it seemed justifiable to test the effect of raising the blood $p \mathrm{H}$ by the buffering action of sodium bicarbonate. Since then this treatment has been used in nine further patients, and this paper reports the results.

\section{METHODS}

Whenever possible arterial blood samples were taken from femoral or brachial arteries and analysed immediately. Capillary blood was used when arterial samples could not be obtained, and this is indicated in the Table by a blank in the column under oxygen tension. Oxygen saturations were determined on a Kipp haemoreflector and converted to partial pressures taking into account body temperature and blood $\mathrm{pH}$ as described by Severinghaus (1958). This method becomes less and less accurate as the oxygen tension approaches normal, and such values are reported in the Table as $>90 \mathrm{~mm}$. $\mathrm{Hg}$. Levels of $p \mathrm{H}$ and $\mathrm{PCO}_{2}$ were

\footnotetext{
1 Present address : Stobhill General Hospital, Glasgow, N.1.
}

determined with a Micro Astrup apparatus (Siggaard Andersen, Engel, Jørgensen, and Astrup, 1960).

The metabolic factor in the acid-base status is expressed as the base excess by the same method. The normal range for this value is regarded as

T A BLE

BLOOD GAS AND ACID BASE VALUES AND THE EFFECTS

\begin{tabular}{|c|c|c|c|c|c|}
\hline Patient & $\underset{p \mathrm{H}}{\text { Blood }}$ & $\begin{array}{l}\mathrm{PCO}_{2} \\
(\mathrm{~mm} . \\
\mathrm{Hg})\end{array}$ & $\begin{array}{c}\text { Base } \\
\text { Excess } \\
(\mathrm{mEq} / \mathrm{l})\end{array}$ & $\begin{array}{c}\mathrm{PaO}_{2} \\
(\mathrm{~mm} \\
\mathbf{H g})\end{array}$ & $\begin{array}{c}\text { Remarks } \\
\text { and Bicarbonate } \\
\text { Dose Given }\end{array}$ \\
\hline 1 & $\begin{array}{l}7 \cdot 18 \\
7 \cdot 56\end{array}$ & 190 & $\begin{array}{l}>+21 \\
>+21\end{array}$ & - & $\begin{array}{l}\text { Coma; } 1,000 \mathrm{mEq} \text { given } \\
\text { by stomach tube over } \\
12 \mathrm{hrs} \\
12 \mathrm{hrs} \text { later; confused }\end{array}$ \\
\hline 2 & $\begin{array}{l}7 \cdot 05 \\
7 \cdot 15 \\
7 \cdot 16 \\
7 \cdot 33\end{array}$ & $\begin{array}{l}165 \\
170 \\
220 \\
102\end{array}$ & $\begin{array}{r}+5 \cdot 5 \\
+21 \\
>+21 \\
+16\end{array}$ & $\begin{array}{l}>90 \\
>90 \\
>90 \\
>90\end{array}$ & $\begin{array}{l}\text { Coma; } 200 \mathrm{mEq} \text { given } \\
\text { I.V.; further } 200 \mathrm{mEq} \\
\text { Stupor; furtstupor } \\
\frac{1}{2} \mathrm{hr} \text { later; st } \\
3 \mathrm{hrs} \text { later; confused }\end{array}$ \\
\hline 3 & $\begin{array}{l}7 \cdot 105 \\
7 \cdot 235 \\
7 \cdot 37\end{array}$ & $\begin{array}{r}120 \\
118 \\
74\end{array}$ & $\begin{array}{l}+3 \cdot 5 \\
+15 \cdot 5 \\
+13\end{array}$ & $\begin{array}{l}64 \\
57 \\
64\end{array}$ & $\begin{array}{l}\text { Coma; } 200 \mathrm{mEq} \text { given } \\
\frac{1}{2} \mathrm{hr} \text { later; confused } \\
12 \mathrm{hrs} \text { later; rational }\end{array}$ \\
\hline 4 & $\begin{array}{l}7 \cdot 165 \\
7 \cdot 21 \\
7 \cdot 28 \\
7 \cdot 42\end{array}$ & $\begin{array}{r}157 \\
145 \\
135 \\
88\end{array}$ & $\begin{array}{l}+11 \\
+21 \\
+18 \\
+20\end{array}$ & $\begin{array}{l}70 \\
-\end{array}$ & $\begin{array}{l}\text { Coma; } 150 \mathrm{mEq} \text { given } \\
\frac{1}{2} \mathrm{hr} \text { later; stupor; further } \\
100 \mathrm{mEq} \text { given } \\
\frac{1}{2} \mathrm{hr} \text { later; confused } \\
24 \mathrm{hrs} \text { later; rational }\end{array}$ \\
\hline 5 & $\begin{array}{l}7 \cdot 18 \\
7 \cdot 23 \\
7 \cdot 42\end{array}$ & $\begin{array}{l}93 \\
96 \\
45\end{array}$ & $\begin{array}{l}+4 \cdot 5 \\
+11 \\
+6.5\end{array}$ & 二 & $\begin{array}{l}\text { Stupor; } 100 \mathrm{mEq} \text { given } \\
\frac{1}{2} \mathrm{hr} \text { later; confused } \\
14 \text { days later; rational }\end{array}$ \\
\hline 6 & $\begin{array}{l}7 \cdot 19 \\
7 \cdot 28 \\
7 \cdot 35\end{array}$ & $\begin{array}{l}95 \\
83 \\
74\end{array}$ & $\begin{array}{l}+1 \\
+5 \\
+8\end{array}$ & $\begin{array}{l}50 \\
46 \\
67\end{array}$ & $\begin{array}{l}\text { Stupor; } 200 \text { mEq given } \\
\frac{1}{2} \text { hr later; confused } \\
24 \text { hrs later; rational }\end{array}$ \\
\hline 7 & $\begin{array}{l}7 \cdot 05 \\
7 \cdot 15 \\
7 \cdot 18 \\
7 \cdot 11 \\
7 \cdot 11\end{array}$ & $\begin{array}{l}150 \\
135 \\
130 \\
155 \\
113\end{array}$ & $\begin{array}{r}+1 \\
+10 \\
+11 \\
+10 \\
\text { Zero }\end{array}$ & $\begin{array}{l}72 \\
62 \\
61 \\
38 \\
-\end{array}$ & $\begin{array}{l}\text { Coma; } 260 \text { mEq given } \\
\frac{1}{2} \mathrm{hr} \text { later; stupor } \\
1 \mathrm{hr} \text { later; confused } \\
1 \mathrm{hr} \text { later; stupor; } 300 \\
\text { mEq given } \\
\text { Coma; died (see text) }\end{array}$ \\
\hline 8 & $\begin{array}{l}7 \cdot 16 \\
7 \cdot 32\end{array}$ & $\begin{array}{l}85 \\
93\end{array}$ & $\begin{array}{r}\text { Zero } \\
+12\end{array}$ & $\begin{array}{l}40 \\
32\end{array}$ & $\begin{array}{l}\text { Coma; } 200 \text { mEq given } \\
\frac{1}{2} \text { hr later; conscious }\end{array}$ \\
\hline 9 & $\begin{array}{l}7 \cdot 11 \\
7 \cdot 24 \\
7 \cdot 37\end{array}$ & $\begin{array}{r}120 \\
110 \\
53\end{array}$ & $\begin{array}{l}-3 \\
+8 \cdot 5 \\
+3\end{array}$ & $\begin{array}{l}\overline{49} \\
46\end{array}$ & $\begin{array}{l}\text { Coma; } 200 \mathrm{mEq} \text { given } \\
\frac{1}{2} \mathrm{hr} \text { later; rational } \\
24 \mathrm{hrs} \text { later; rational }\end{array}$ \\
\hline 10 & $\begin{array}{l}7 \cdot 25 \\
7 \cdot 33 \\
7 \cdot 35 \\
7 \cdot 36\end{array}$ & $\begin{array}{r}108 \\
85 \\
65 \\
47\end{array}$ & $\begin{array}{l}+6 \\
+12 \cdot 5 \\
+9 \\
\text { Zero }\end{array}$ & $\begin{array}{l}49 \\
48 \\
51 \\
59\end{array}$ & $\begin{array}{l}\text { Stupor; } 100 \mathrm{mEq} \text { given } \\
3 \mathrm{hrs} \text { later; confused } \\
48 \mathrm{hrs} \text { later; rational } \\
3 \text { months later as out- } \\
\text { patient }\end{array}$ \\
\hline
\end{tabular}


$\pm 2.5 \mathrm{mEq} / 1$, but in the context of this paper this has little relevance and the 'normal' in any instance is regarded as that value of base excess which, in combination with the actual $\mathrm{PCO}_{2}$, would produce a resulting $p \mathrm{H}$ close to 7.38. This is easily determined from the Siggaard Andersen nomogram on the $p \mathrm{H} / \log \mathrm{PCO}_{2}$ graph (Siggaard Andersen, 1962) by considering the theoretical equilibration line required to produce the desired $p \mathrm{H}$ at the same $\mathrm{PcO}_{2}$. This estimate is preferred because it can be directly converted into the required dose in milliequivalents of bicarbonate, taking into account the body weight (Mellemgaard and Astrup, 1960). In the circumstances it was usually necessary to make a rough estimate of body weight based on inspection, as it was not practicable to weigh the patients during their acute illness. As soon as the results were obtained the appropriate dose of bicarbonate was given. A further arterial sample was taken and clinical assessment was made not more than half an hour after the dose.

In the first patient sodium bicarbonate was given by stomach tube in divided doses. By an error in administration he was given approximately $1,000 \mathrm{mEq}$ rather than the intended 250 $\mathrm{mEq}$ over 12 hours. The other patients were given a solution of molar bicarbonate $(1 \mathrm{mEq} / \mathrm{ml}$.; $8.4 \% \mathrm{w} / \mathrm{v}$ sodium bicarbonate) intravenously. It was not thought justifiable to withhold other treatment from these very acutely ill patients, but as far as possible care was taken not to alter these treatments during the period of observation or to take any sample within an hour of a nikethamide injection. Other treatment consisted of oxygen at 2 or $41 . / \mathrm{min}$. through a double nasal catheter previously described (Addis, 1963), antibiotics, and nikethamide, which was usually given as a single intravenous injection of 6 to $8 \mathrm{ml}$. at the start of treatment and $2 \mathrm{ml}$. intramuscularly from time to time thereafter.

The level of consciousness, though easily appreciated clinically, is more difficult to describe in a precise way. The terms used in this paper should be interpreted as follows:

Coma: patient makes no response to stimuli except perhaps to move slightly when an artery is punctured.

Stupor: patient is clearly not unconscious, opens his eyes and may follow with them, but does not communicate. He usually responds vigorously to arterial puncture.

Confused: patient is conscious, and co-operative within limits ; answers questions, but not always sensibly.
Rational: an apparently normal mental state. $\stackrel{\overrightarrow{\overrightarrow{\vec{D}}}}{\vec{\theta}}$ All these assessments were made by the same $\bar{C}$ observer, but the intermediate grades should not $\overline{ }$ be interpreted in an absolute way. The main $\frac{\bar{T}}{7}$ reason for their use is to indicate the direction, $\stackrel{\mathbb{Q}}{\Omega}$ and roughly the extent, of any change.

\section{CASES}

The patients' ages ranged from 45 to 70 years. Two (cases 4 and 5) were women, and three (cases 1,6 , and 7) were extremely obese. All had a previous history of chronic cough and spit, and all had had repeated attacks of winter bronchitis. Only the two women were in frank congestive cardiac failure at the time of the exacerbation, but all had varying degrees of clinical and electrocardiographic evidence of right heart hypertrophy, and this was confirmed at necropsy in the four patients who died.

\section{RESULTS}

The results are shown in the Table. Except after the second dose in patient 7 , a consistent rise in the $p H$ was achieved, and with this a comparable improvement in the level of consciousness. The change in $p \mathrm{H}$ was mainly due to the increase in metabolic compensation as measured by the rise in the base excess. Any important reduction in $\mathrm{PCO}_{2}$ tended to follow the response in $\mathrm{pH}$ and level of consciousness, as would be expected from the coughing and increased ventilation which results.

Patients 1, 2, 7, and 8 died during the illness. As already indicated, patient 1 had been very ill with severe respiratory failure for a long time, and on the fourth day of a further exacerbation bicarbonate was given when it seemed that he could not survive the night. In the event he improved noticeably and survived a further 36 hours. Patient 2 died following a haematemesis 12 hours after the bicarbonate was given. Necropsy showed a haemorrhagic gastritis without ulceration. Haemorrhage has been shown to be a complication of hypoxia (Simpson, 1957). The blood clotting mechanism had not been investigated in this patient. Patient 7 improved after the initial dose of bicarbonate but failed to maintain this, probably due to the fall in tissue oxygen tension suggested by the fall in $\mathrm{PaO}_{2}$ to $38 \mathrm{~mm}$. $\mathrm{Hg}$. After the second dose had produced no immediate response, $8 \mathrm{ml}$. of nikethamide was injected intravenously. He then collapsed pulseless and without detectable respiration. Artificial respiration was applied but the patient did not recover conscious- 
ness and died nine hours later. Necropsy showed only suppurative bronchitis and bronchopneumonia. The brain was not examined. Patient 8 died of uraemia one week after treatment had produced a satisfactory initial response. Necropsy showed amyloid-like changes in the kidneys and pneumonic consolidation which had been detected clinically and accounted for the persistent hypoxia in spite of improved carbon dioxide tensions.

$p$ H CHANGES The $p \mathrm{H}$ rose above the desired level of 7.2 immediately after the bicarbonate had been given, except in patients 2 and 7. Case 2 was monitored on a spirometer and it was probably due to the dead space of this instrument that the $\mathrm{CO}_{2}$ pressure reached a level beyond that where the maximal permissible dose of bicarbonate could buffer the resulting $p \mathrm{H}$ fall. The spirometer was removed after the third sample with a resulting improvement in keeping with the above suggestion. The first dose of bicarbonate given to case 7 was too small because the patient's weight (115 kg.) had been underestimated and a less than satisfactory response in the $p H$ was accepted. A different outcome might have followed $400 \mathrm{mEq}$ as an initial dose. There is not enough evidence to warrant any conclusion as to the cause of failure at the second attempt in this patient. The very low $\mathrm{PaO}_{2}$, as indicated, must have been important.

$\mathrm{PCO}_{2}$ CHANGES Apart from the special circumstance of case 2, no rise in $\mathrm{CO}_{2}$ tensions followed the administration of bicarbonate. Instead the $\mathrm{CO}_{2}$ tension fell only gradually after the improvement in consciousness with treatment of the acidosis, and this fall continued into convalescence. The rapid change in consciousness contrasted with the relatively slow fall in $\mathrm{CO}_{2}$ tension, suggesting that the improvement was caused by the $p \mathrm{H}$ change directly.

BASE EXCESS CHANGES In each case an appropriate increase in base excess occurred immediately. As discussed above, the second attempt in case 7 was an exception to this rule, for which no convincing explanation has been found.

$\mathrm{PaO}_{2}$ CHANGes There was little consistent variation in this value during the reported observations. It is probably significant that two of the patients who died had the lowest arterial oxygen tensions.

CHANGES IN CONSCIOUSNESS As expected, there was a prompt improvement in consciousness each time a satisfactory rise in $\mathrm{pH}$ was produced, without there being a close relation to changes in $\mathrm{PCO}_{2}$.

\section{DISCUSSION}

When acute respiratory failure occurs in chronic respiratory disease, any new treatment under trial must take second place to the urgent needs of the patient. It is not ethically justifiable to withhold established methods of treatment even when these may interfere with the assessment of the innovation. Oxygen tensions obtained in this series suggest that the response was not due to improved oxygenation. Moreover nikethamide was not given in any instance between the initial and postbicarbonate blood sampling, so that the changes observed are believed to have resulted from the blood buffering effect. The finding that precise objective measurements of the response of the blood $p \mathrm{H}$ and blood buffer show the same pattern in each instance in conformity with the expected result on the basis of established biochemical principles may be considered to compensate for these defects in design which are due to the circumstances of this trial.

The figures also lend support to previous suggestions (Westlake et al., 1955; Addis, 1961 ; Flenley, Hutchison, and Donald, 1963) that a pH about 7.2 may be regarded as the minimum 'safe' level in this condition. This may well be true of all but the most transient disturbances of acid-base balance (Siggaard Andersen, 1963). It appears that the proximate cause of the coma is mainly the low blood $p \mathrm{H}$, the clinical picture being very similar to that described by Brooks and Feldman (1962) in the metabolic acidosis of 'neostigmine resistant curarization' in which the response to bicarbonate therapy has proved equally dramatic. The metabolic acidosis existing in exacerbations of chronic respiratory failure is obscured if the numerical base excess value is considered alone in isolation from the $\mathrm{PaCO}_{2}$ at the time of sampling.

The 'normal' value must be different in each patient whose resting $\mathrm{PaCO}_{2}$ is significantly elevated, and will, for example, be about +10 $\mathrm{mEq} / \mathrm{l}$. for a $\mathrm{PaCO}_{2}$ of $70 \mathrm{~mm}$. $\mathbf{H g}$. In such a patient a base excess value in the conventional normal range represents a significant but concealed metabolic acidosis. This is an example of the sort of interpretative difficulties with acid-base data cited by Schwartz and Relman (1963).

The fundamental defect seems to be the failure of metabolic compensation (as an increase in the blood concentration of sodium bicarbonate) to 
keep pace with the rising carbon dioxide tension. There seem to be two possible mechanisms for this critical failure. The concomitant hypoxia may bring about a lactic acid acidosis (Huckabee, 1958) or perhaps result in a depression of renal hydrogen ion secretion and bicarbonate formation. The base excess has remained at or about the level needed to maintain the $p \mathrm{H}$ about 7.35 in those patients who recovered from the acute episode and has gradually fallen, in step with the $\mathrm{PCO}_{2}$, as the patients move towards recovery.

\section{CONCLUSIONS}

Oxygen should be given at a rate sufficient to keep the arterial $\mathrm{Po}_{2}$ above $40 \mathrm{~mm}$. $\mathrm{Hg}$ without $\mathrm{CO}_{2}$ rebreathing. A plastic double nasal catheter and a flow rate of $41 . / \mathrm{min}$. seems an adequate and convenient method of achieving these objects in most patients.

The blood $p \mathrm{H}$ should be raised above $7 \cdot 2$ by the intravenous injection of $100 \mathrm{mEq}$ aliquots of sodium bicarbonate.

The patient's progress should be followed with at least $p \mathrm{H}$ and $\mathrm{PCO}_{2}$ studies on capillary blood as an adjunct to clinical assessment. If a $\mathrm{PaO}_{2}$ above $40 \mathrm{~mm}$. $\mathrm{Hg}$ or a $p \mathrm{H}$ above 7.2 cannot be obtained and maintained, assisted respiration should be considered.

\section{SUMMARY}

Sodium bicarbonate was given on 10 occasions when the blood $p \mathrm{H}$ was found to be below $7 \cdot 2$ in acute exacerbations of chronic bronchitis and emphysema. In 10 instances the $p \mathrm{H}$ rose as expected and eight of these rises could be judged satisfactory.

The level of consciousness is again shown to be more closely related to the blood $p \mathrm{H}$ than to the carbon dioxide tension and to improve markedly above $7 \cdot 2$.
It is suggested that in this situation there is failure of the sodium bicarbonate concentration in the blood to rise as rapidly as the carbon dioxide pressure, thus permitting a dangerous rise in the hydrogen ion concentration.

Intravenous sodium bicarbonate should be given in sufficient amount to make good this deficiency and raise the blood $p \mathrm{H}$ to at least $7 \cdot 2$.

An arterial oxygen tension above $40 \mathrm{~mm} . \mathrm{Hg}$ is probably essential also for successful treatment.

I wish to thank Dr. S. Lazarus, Dr. L. D. W. Scott, and Dr. Gavin Shaw, the consultants in charge of the medical units at the Southern General Hospital, for allowing me to treat their patients. I wish to thank them also, and most particularly Dr. W. S. T. Thomson, consultant biochemist, for their encouragement and support in this work.

\section{REFERENCES}

Addis, G. J. (1961). Tracheotomy and emphysema. Lancet, 2, 1311. (1963). A comfortable nasal catheter for oxygen therapy. Ibid., 1,1084 .

Brooks, D. K., and Feldman, S. A. (1962). Metabolic acidosis. Anaesthesia, 17, 161.

Flenley, D. C., Hutchison, D. C. S., and Donald, K. W. (1963). Controlled oxygen therapy in respiratory failure. Scot. med. J., $8,456$.

Huckabee, W. E. (1958). Relationships of pyruvate and lactate during anaerobic metabolism. III. Effect of breathing low oxygen gases. J. clin. Invest., 37, 264.

Kety, S. S., Polis, B. D., Nadler, C. S., and Schmidt, C. F. (1948). The blood flow and oxygen consumption of the human brain in diabetic acidosis and coma. Ibid., 27, 500 .

Mellemgaard, K., and Astrup, P. (1960). The quantative determination of surplus amounts of acid or base in the human body. Scand. $J$. clin. Lab. Invest., 12, 187.

Schwartz, W. B., and Relman, A. S. (1963). A critique of the parameters used in the evaluation of acid-base disorders. New Engl. J. Med., 268, 1382 .

Severinghaus, J. W. (1958). Blood $\mathrm{O}_{2}$ dissociation line charts; man In Handbook of Respiration. [National Academy of Sciences] P. 72. W. B. Saunders, Philadelphia and London

Siggaard Andersen, O. (1962). The pH-log $\mathrm{PCO}_{2}$ blood acid-base nomogram revised. Scand. J. clin. Lab. Invest. 14, 598. (1963). The acid-base status of the blood. Ibid., 15, Suppl. 70

- Engel, K., Jørgensen, K., and Astrup, P (1960). A micro method for determination of $\mathrm{pH}$, carbon dioxide tension, base excess and standard bicarbonate in capillary blood. base excess

Simpson, T. (1957). Anoxia in emphysema. Lancet, 2, 105.

Westlake, E. K., Simpson, T., and Kaye, M. (1955). Carbon dioxide narcosis in emphysema. Quart. J. Med., 24, 155. 